\title{
COLD WATER IMMERSION TEST IN PATIENTS WITH VIBRATION DISEASE
}

\author{
Cheng-Po CHANG $\dagger$ \\ 振動病患者に括ける冷水浸漬試験 \\ 張 正 博*
}

\begin{abstract}
Peripheral vascular disorder is one of the most important symptoms in diagnosing vibration disease. Several kinds of tests have been introduced to evaluate the peripheral vascular function. Among those tests, cold water immersion test has been mostly applied. In Japan, the generally used method is to measure the skin temperature of one finger of the hand immersed up to the wrist joint in water at $5^{\circ} \mathrm{C}$ for 10 minutes. However, because the suffering during the test is so severe and some unfavorable warning symptoms have been observed during group examinations, a safer and milder method is more desirable. In order to examine the applicability of the test by using water at $10^{\circ} \mathrm{C}$ in comparison with that at $5^{\circ} \mathrm{C}$, and to know the degree of suffering during the tests, a comparative study was performed. Sixteen students and 29 patients with vibration disease joined in this study. The results suggest that water at $10^{\circ} \mathrm{C}$ can be an effective stimulus, if the immediate rewarming response is used for evaluation. The self-rating scores revealed that the suffering was milder in case of water at $10^{\circ} \mathrm{C}$ than at $5^{\circ} \mathrm{C}$ for both the students and the patients. And the patients seemed to suffer more from chest discomfort than the students.
\end{abstract}

\section{INTRODUCTION}

It has long been known that using handheld vibratory tools may induce peripheral vascular disorder since Loriga (1911) first described "vascular spasm" or white finger in the hands of pneumatic tool miners. ${ }^{1)}$ A similar name "Hakurōbyō" (white wax disease) was used to describe the vibration-induced intermittent blanching attacks of the fingers in Japan for some years. However, the name "Raynaud's phenomenon of occupational origin" suggested by Agate $^{2)}$ has been widely accepted. Later, it was found that vibrating tools may cause not only the peripheral vas-

\footnotetext{
$\dagger$ Department of Environmental Health, Kurume University School of Medicine Received for publication, July 6, 1976

* 久留米大学医学部環境衛生学教室 昭和 51 年 7 月 6 日受付
}

cular disorder but also primary lesions in the musculoskeletal system and the peripheral nervous system. ${ }^{3-5)}$ And some authors (Andreeva-Galanina, Takamatsu and Futatsuka, Matoba et $a l.)^{6-8)}$ emphasized that central nervous system can also be affected. Thus, "vibration disease" has now been considered as an entity of systemic disease in Japan.

Some cases with symptoms of vibration disease have been reported in Japan since 1938.4) However, systematic researches on the disease had not been done until 1965 when the outbreak of a large number of patients with vibration disease among chain saw operators became a nationwide social problem. ${ }^{9,10)}$ A series of epidemiologic studies revealed the severe situation with vibration disease among the forest workers throughout Japan.

Peripheral vascular disorder is one of the most important symptoms in diagnosing vibration disease. Several kinds of tests have been 
used to evaluate the peripheral vascular function or to provoke Raynaud's phenomenon. ${ }^{2-}$ 4,11) Among those tests, cold water immersion test has been mostly used for three reasons: 1) it can give the information of the early change in the peripheral vascular function before obvious disorder occurs, 2) it can also be used as a provocative test for Raynaud's phenomenon, and 3) the procedure per se is simple and it is an economic test as a screening test.

In Japan, the method generally used is to measure the change in skin temperature from one finger of the hand immersed up to the wrist joint in water at $5^{\circ} \mathrm{C}$ for 10 minutes. ${ }^{12}$ However, because of the severe suffering during the immersion, some subjects could not get through the test and several cases with pre-shock state were observed during group examinations. So, a safer and milder method is more desirable.

To raise the water temperature seems to be a practicable method to reduce the suffering during the immersion test. In order to examine the applicability of the test by using water at $10^{\circ} \mathrm{C}$ in comparison with that at $5^{\circ} \mathrm{C}$, and to know the degree of suffering during the tests, a comparative study was made preliminarily in students and then in patients with vibration disease.

\section{SUBJECTS AND METHODS}

\section{Preliminary studies in students}

1) Subjects. Sixteen healthy male medical students aged 19-26 years (ave. 22.6) joined in these studies. They were divided into two groups. Eight students (group 1) were examined by the $10^{\circ} \mathrm{C}$-water immersion test first, then about 4 hours later by the $5^{\circ} \mathrm{C}$-water immersion test. The other 8 students (group 2) were examined by the two tests vice versa in sequence.

The subjects were asked to smoke and to drink as little as possible since the previous day, and no smoking was allowed since one hour before they entered the examination room. ${ }^{13)}$ They were also instructed not to take extra exercise and thermal exposure since the morning of the examination day. They were allowed to dress as they liked, but they had to dress the same kinds of clothes at the two tests.

2) Methods. The room temperature was maintained between 20.5 and $22.5^{\circ} \mathrm{C}$. The humidity was around $70-75 \%$, and the wind was less than $0.3 \mathrm{~m} / \mathrm{sec}$. The outdoor temperature was between 22.1 and $25.2^{\circ} \mathrm{C}$. All the tests were conducted between $10 \mathrm{a} . \mathrm{m}$. and 4 p.m. in October 1975.

Two kinds of water temperature were applied, they were controlled at $5^{\circ} \mathrm{C}$ and $10^{\circ} \mathrm{C}$ within $\pm 0.5^{\circ} \mathrm{C}$ accuracy. The water was stirred very slowly during the immersion. A waterproof icebox was used as the container.

In order to evaluate the suffering during the test, a self-rating scale from grade 1 to 5 was used. The suffering was expressed in terms of pain in the immersed hand, tightness sensation in the chest, and general suffering. The severity of each item was scored into 5 grades, i.e. $1=$ not at all ; $2=$ slight ; $3=$ fair ; $4=$ severe ; and $5=$ extreme. The subjects were instructed to report their subjective evaluation of the suffering by a number of three figures corresponding to pain, tightness sensation in the chest and general suffering. For instance, the number 423 means that the subject feels severe pain in the immersed hand with slight tightness sensation in the chest and the general suffering is fairly hard for him.

After entering the examination room, the subjects were asked to answer a simple questionnaire including 26 items on the general physical and mental conditions for the examination day and the previous day. Blood pressure was measured and physical examination was performed before the test to rule out contraindicated conditions. Then, they were seated in chairs relaxed and the detail of the procedure was explained to them. About 30 minutes later, the cold water immersion test was carried out.

Two sets of thermistor thermometers were applied to the immersed and the non-immersed hands respectively. For each hand, the thermosensory part of the thermometer was attached to the dorsal surface of the distal phalanx of the middle finger, just proximal to the nail, by means of adhesive tape. And to 
the finger to be immersed a thin layer of vaseline was applied over the adhesive tape and the borders of the tape for making it waterproof.

The finger skin temperatures of both hands were taken simultaneously every one minute before (for $5 \mathrm{~min}$ ) during (for $10 \mathrm{~min}$ ), and after (for $30 \mathrm{~min}$ ) the immersion. - The average of the skin temperature during the 5 minutes prior to the immersion was regarded as the initial finger skin temperature. At the same time, the subjects were asked to report their subjective feeling of suffering according to the self-rating scale every one minute. After the initial finger skin temperature had been recorded, the right hand was immersed into the well-stirred cold water $\left(10^{\circ} \mathrm{C}\right.$ or $\left.5^{\circ} \mathrm{C}\right)$ up to the wrist joint for 10 minutes. The water bath was put beside the chair and the height of the water level was so adjusted that the subject could put his hand relaxed in the water without awkward posture of the arm and the trunk. After 10 minutes of immersion, the immersed hand was removed from the water, wiped dry with towel and rested on the armrest and the recordings were continued for 30 minutes. Then the subjects were interviewed to describe the course of suffering during and after the 10-minute immersion, and other sufferings that could not be expressed by the self-rating scale. And about 4 hours later, they took the second immersion test of different water temperature $\left(5^{\circ} \mathrm{C}\right.$ or $\left.10^{\circ} \mathrm{C}\right)$ with the same procedure. After the two tests had been finished, the subjects were interviewed again to describe the difference in suffering between the two tests and to report which test they preferred.

To evaluate the immediate rewarming response after the 10-minute immersion, three indices were used in this study:

(a) Recovery activity ${ }^{14)}$

$$
=\frac{\left(T_{11}-T_{10}\right)+\left(T_{12}-T_{10}\right) / 2+\left(T_{13}-T_{10}\right) / 3}{3}
$$$$
\left({ }^{\circ} \mathrm{C} / \mathrm{min}\right)
$$

(b) Rewarming rate $=\left(\mathrm{T}_{13}-\mathrm{T}_{10}\right) / 3$ $\left({ }^{\circ} \mathrm{C} / \mathrm{min}\right)$

(c) Recovery rate $=\frac{T_{13}-T_{10}}{T_{0}-T_{10}} \times 100$

Where $\mathrm{T}_{0}$ : the initial skin temperature of the immersed finger (the average skin temp. during the 5 minutes before the immersion)

$T_{10}$ : the skin temperature of the immersed finger at the end of the 10-minute immersion

$T_{11}$ : the skin temperature of the immersed finger one minute after removal of the hand from the water

$T_{12}$ : the skin temperature of the immersed finger two minutes after removal of the hand from the water

$T_{13}$ : the skin temperature of the immersed finger three minutes. after removal of the hand from the water

2. Studies in patients with vibration disease

1) Subjects. Twenty-nine newly hospitalized male patients with vibration disease, aged 3256 years (ave. 46.8), participated in these studies. Sixteen of them $(55.2 \%)$ were at the stage II and the other thirteen (44.8\%) were at the stage III according to the AndreevaGalanina's classification. Twenty-seven of the patients were chain saw operators with an average job history of $11.6 \pm 5.1$ years $(2-18.3$ ys), and the other two patients were bush cleaner operators with job histories of 12.1 and 16.7 years. Of the 29 patients, 13 had history of Raynaud's phenomenon in the past; however, only 4 of the 13 patients had Raynaud's phenomenon within one year prior to their hospitalization.

2) Methods. In consideration of the patients' physical and mental conditions and to avoid any interference with the treatment scheme, the two tests were performed on different days (the 4 th and 5 th or the 5 th and 6 th days of hospitalization) but at the same hour of the day. According to the treatment scheme, medication would be given from the 7th hospitalization day, after several kinds of precise examinations were completed. As usual, the worse hand that the patient felt was used for immersion. The skin temperature was taken from the worst finger among the index, middle and ring fingers, and the 
skin temperature of the same finger of the other hand was read. All the patients took the test of water at $10^{\circ} \mathrm{C}$ first and were followed by the test of water at $5^{\circ} \mathrm{C}$ on different days. Otherwise there was nothing different in the methods from those used in the preliminary studies in students.

All the tests were conducted in October, November and December 1975. The wards of the hospital were air-conditioned at around $20-24^{\circ} \mathrm{C}$ by the central heating system. The temperature of the examination room was between 21.0 and $22.5^{\circ} \mathrm{C}$. The outdoor temperatures of the examination days were 21$22^{\circ} \mathrm{C}$ in October, $12.5-13.2^{\circ} \mathrm{C}$ in November and $6-7^{\circ} \mathrm{C}$ in December. Because the patients seldom came out of the hospital since they were hospitalized, the influence of the outdoor temperature was thought to be lessened after three days of hospitalization.

\section{RESULTS}

As to the pattern and the degree of the response to cold water immersion, there was no significant difference between the two groups of students for both the immersed and the non-immersed hands. However, the selfrating scores for the suffering during the tests were different in some aspects between the two groups of students. So, the results of self-rating scores will be presented separately by groups.

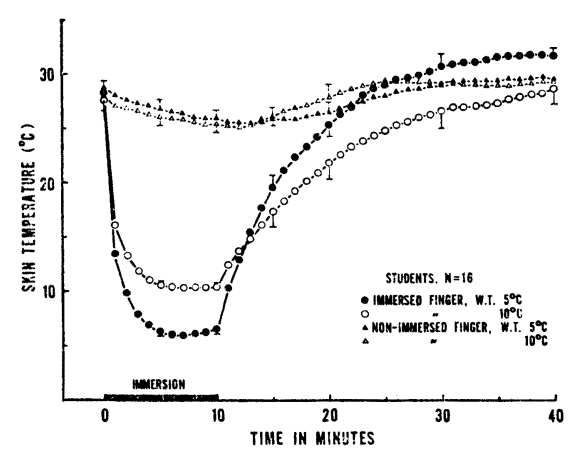

Fig. 1. Changes in finger skin temperature during the two immersion tests for the students. Vertical bars indicate standard errors.

The initial skin temperature was the average skin temperature during the 5 minutes prior to the immersion.

\section{Changes in finger skin:'temperature dur- ing the test}

Figures 1 and 2 show the courses of changes in finger skin temperatures of both the immersed and the non-immersed hands during the two immersion tests for the 16 students and the 29 patients respectively.

1) Pre-immersion state. The initial skin temperatures of four students increased by about $2-3^{\circ} \mathrm{C}$ in the afternoon when the second immersion test was performed. It was not sure whether the increase was due to the influence of the first immersion test in the morning or other reasons such as circadian rhythm. However, from the results of the rewarming response of the two tests (which will be presented later), it seemed that such a difference in the initial skin temperature did not cause remarkable influence on the rewarming response. For each patient, the difference in initial skin temperature between the two tests was less than $2^{\circ} \mathrm{C}$ and could be neglected.

There was no significant correlation between the initial skin temperature and the rewarming response for both the students and the patients. Though the average initial skin temperature of the students was a little higher than that of the patients, the difference was not statistically significant.

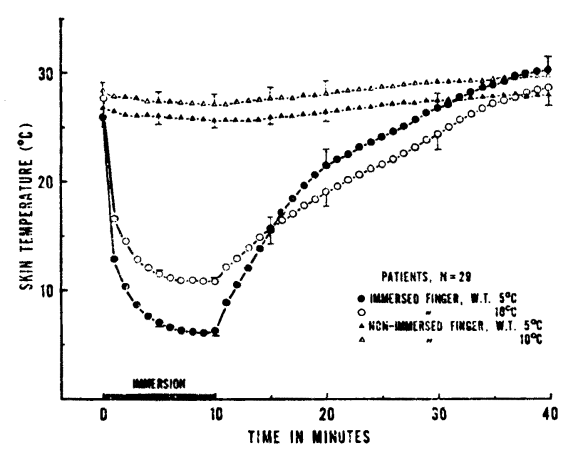

Fig. 2. Changes in finger skin temperature during the two immersion tests for the patients. Vertical bars indicate standard errors.

The initial skin temperature was the average skin temperature during the 5 minutes prior to the immersion. 
Table 1. Evaluation of the rewarming response after the 10-minute immersion by different indices.

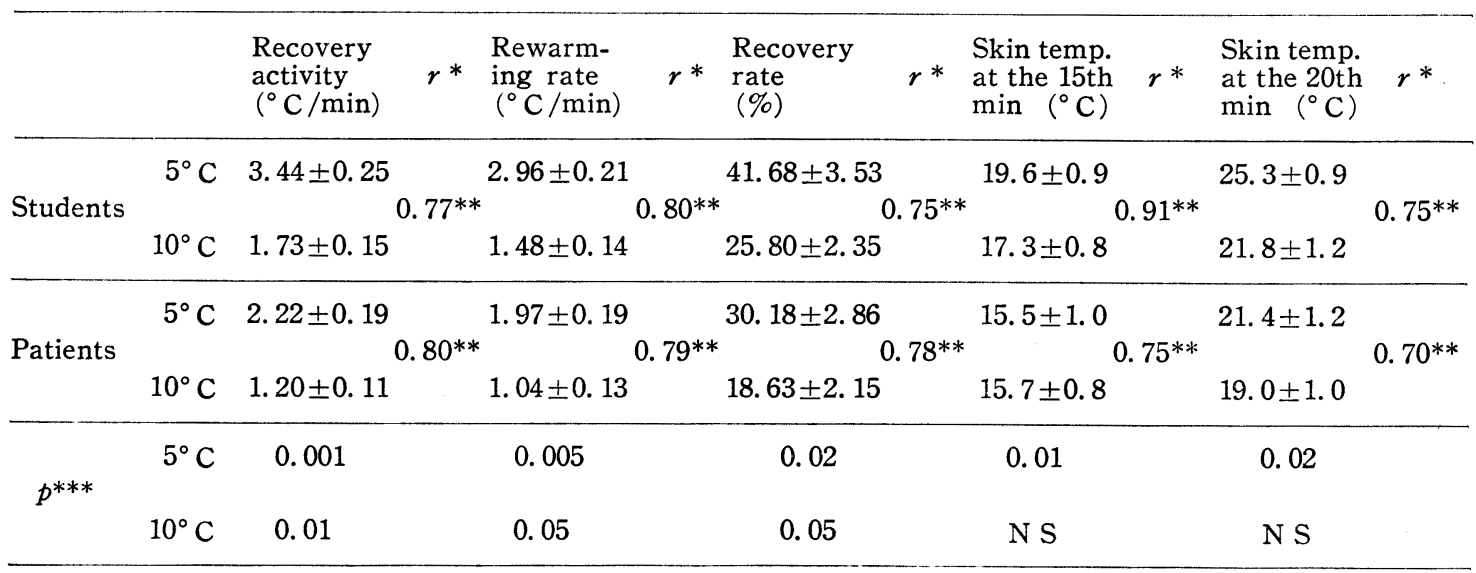

(All the index values are mean $\pm \mathrm{S}$. E.), *Correlation coefficient $\left(5^{\circ} \mathrm{C} v s .10^{\circ} \mathrm{C}\right)$, $* * p<0.001$, ***Level of significance for the difference between the students and the patients (Student's $t$-test), NS: Not significant

2) Changes in the immersed hand during the immersion. As soon as the immersion started, the finger skin temperature dropped sharply close to the water temperature in the first 5-6 minutes and then with slow decrease became relatively stable with or without hunting reaction of Lewis ${ }^{15)}$ in the succeeding minutes of immersion in both cases $\left(5^{\circ} \mathrm{C}\right.$ and $\left.10^{\circ} \mathrm{C}\right)$ of water temperature. Hunting reaction occurred more often and stronger in the case of water at $5^{\circ} \mathrm{C}$ than at $10^{\circ} \mathrm{C}$. Fifteen students $(93.7$ $\%)$ and 11 patients $(37.9 \%)$ showed hunting reaction in the case of water at $5^{\circ} \mathrm{C}$, while only 7 students $(43.8 \%)$ and 9 patients $(31.0$ $\%$ ) showed the reaction in the case of water at $10^{\circ} \mathrm{C}$. The difference between the students and the patients in the occurrence of hunting reactions was significant ( $p=0.0002$, Fisher's exact test, one-tailed) in the case of water at $5^{\circ} \mathrm{C}$, but not in the case of water at $10^{\circ} \mathrm{C}$.

3) Changes in the immersed hand after the 10-minute immersion. After removal of the immersed hand from the cold water, there was a rapid linear increase in the skin temperature in the first 5-10 minutes and then the increase became gentle. The rewarming response was greater in the case of water at $5^{\circ} \mathrm{C}$ than at $10^{\circ} \mathrm{C}$.

Table 1 shows the significant correlation between the response in the case of water at $5^{\circ} \mathrm{C}$ and that at $10^{\circ} \mathrm{C}$ by different indices for both the students and the patients. And the individual recovery activities in both cases were plotted in Fig. 3 which shows the correlation more clearly.

As shown in the lowest rank of Table 1, there was a significant difference in rewarming response between the students and the patients in terms of all the indices in both cases of water temperature except the skin temperature at the 15 th minute and that at the 20 th minute in the case of water at $10^{\circ} \mathrm{C}$.

4) Changes in the non-immersed hand. As the immersion of the contralateral hand started, the skin temperature of the non-immersed

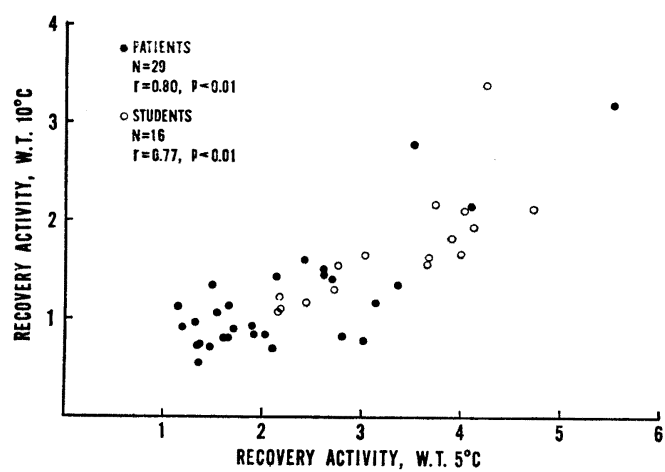

Fig. 3. The correlation between the recovery activity in the case of water at $5^{\circ} \mathrm{C}$ and that at $10^{\circ} \mathrm{C}$ for the students and the patients. $(r$ : correlation coefficient) 

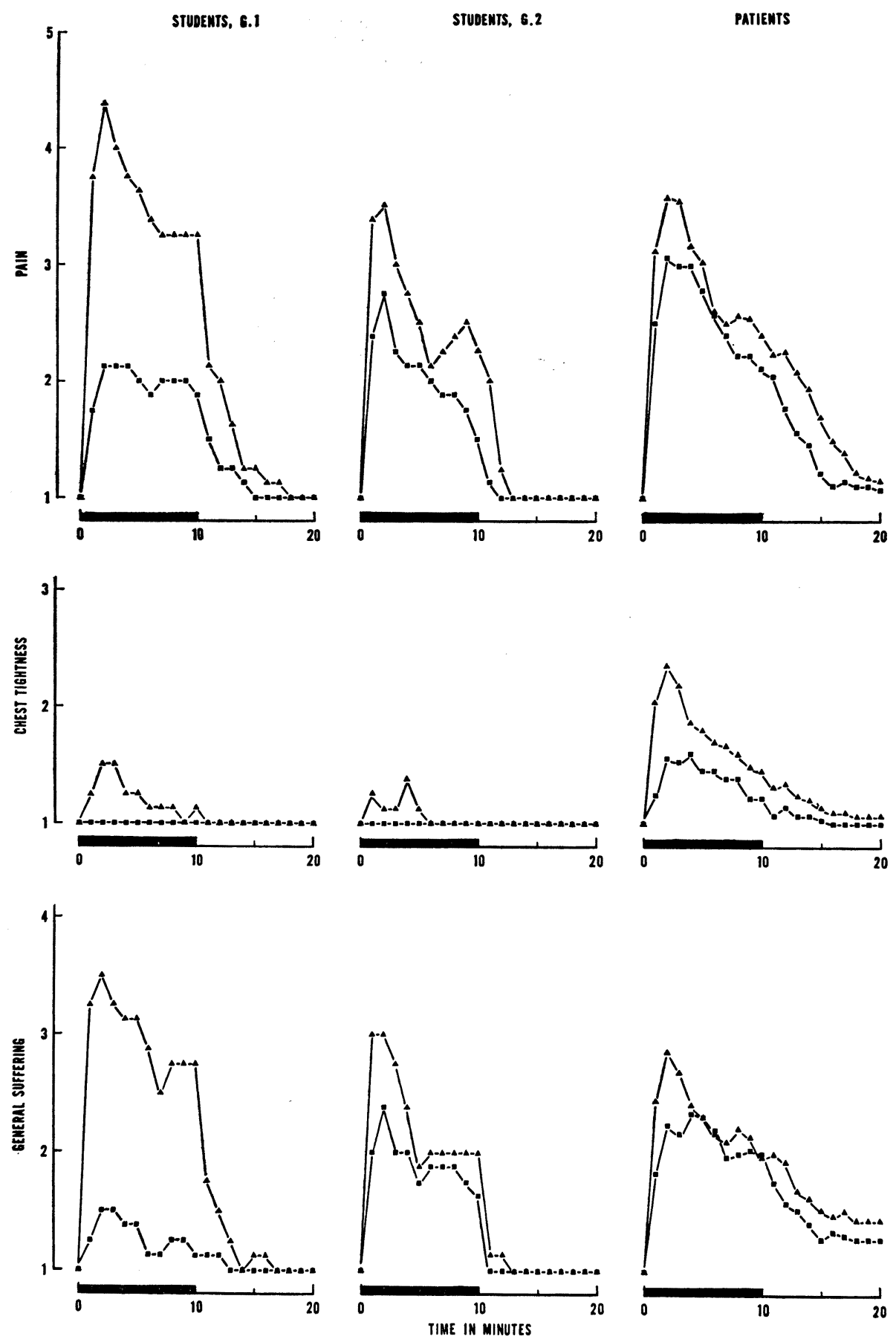

Fig. 4. The transitions of suffering in terms of pain, tightness sensation in the chest, and general suffering during the two immersion tests. Each point is the average self-rating score from the subjects of the group (S. E. $=0-0.25$ ).

Thick bars on the time axes indicate the period of immersion. The initial score was the average score during the 5 minutes prior to the immersion. ( $\Delta$ water at $5^{\circ} \mathrm{C}$; water at $10^{\circ} \mathrm{C}$ ) 
finger also dropped, though much slower, and it tended still to decline until 2-3 minutes after the immersed ${ }^{\prime}$ hand had been removed from the cold water (Figs. 1 and 2). From the individual data, most of the patients showed such a fluctuation in the skin temperature of the non-immersed finger less than the students in both cases. The average difference of the lowest and the highest temperatures of the non-immersed finger during the first 20 minutes of the test for the students was 3.34 $\pm 0.38^{\circ} \mathrm{C}$ (mean $\pm \mathrm{S}$. E. $)$ in the case of water at $5^{\circ} \mathrm{C}$ and $3.05 \pm 0.46^{\circ} \mathrm{C}$ in the case of water at $10^{\circ} \mathrm{C}$, while that for the patients were $2.13 \pm$ $0.28^{\circ} \mathrm{C}$ and $2.47 \pm 0.25^{\circ} \mathrm{C}$ respectively. There was no significant difference in temperature change in the non-immersed finger between the two tests for both the students and the patients. However, the difference between the students and the patients was significant in either case of water temperature $(p<0.02$, Student's $t$-test).

\section{Suffering during the test}

Figure 4 shows the transitions of the suffering expressed in pain, tightness sensation in the chest, and general suffering by selfrating scores according to the 5 grade scale during the first 20 minutes of the two tests. Generally speaking, the suffering was milder in the case of water at $10^{\circ} \mathrm{C}$ than at $5^{\circ} \mathrm{C}$.

At interview, all the 16 students and 23 of the 29 patients $(79.3 \%)$ reported that they suffered less in the case of water at $10^{\circ} \mathrm{C} ; 5$ patients $(17.2 \%)$ preferred to be tested with water at $5^{\circ} \mathrm{C}$; and one patient said he suffered equally in both cases. The difference in the subjective evaluation of the suffering between the two tests was significant for both the students and the patients $(p<0.0001$ and $p<$ 0.001 respectively, sign test, one-tailed).

For the students, the differences in the degree of pain and of general suffering between the two tests were greater for group 1 than group 2. The difference between the two groups of students was thought to be due to the different sequence in experiencing the suffering. However, the tightness sensation in the chest seemed to be negligible in either case of water temperature for both groups.

Though it is hard to make a precise com-

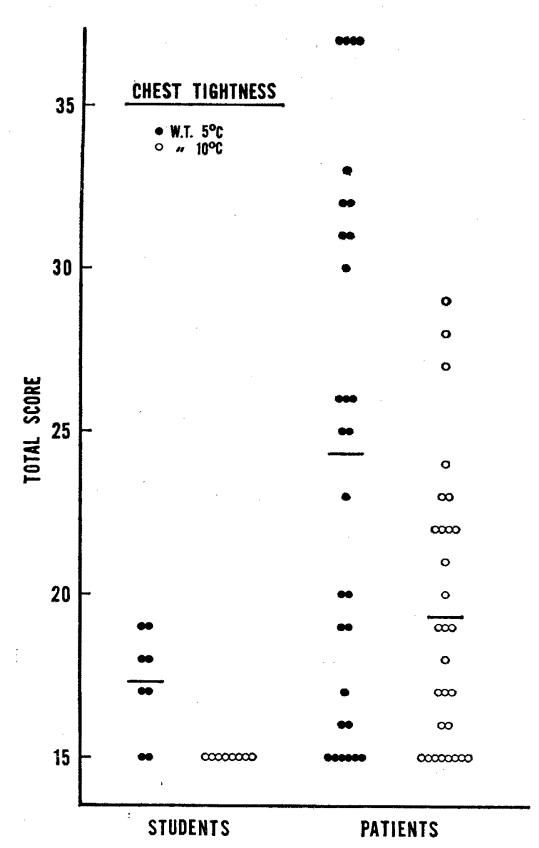

Fig. 5. The individual total scores for the tightness sensation in the chest during the first 15 minutes of the two immersion tests for the students of group 1 and the patients. Total score of 15 means that the subject suffered nothing at all.

parison between the subjective data of the students and of the patients, it is remarkable that the patients seemed to suffer more tightness sensation in the chest than the students. in both cases of water temperature. For the students of group 1 and the patients who took the two tests in the same sequence, the individual total scores for tightness sensation in :the chest are plotted in Fig. 5. The individual data revealed that no student and much less patients suffered from chest discomfort in the case of water at $10^{\circ} \mathrm{C}$ than at $5^{\circ} \mathrm{C}$.

According to the reports of the students and the patients, the suffering during the test can be summarized below. In the case of water at $5^{\circ} \mathrm{C}$, the severe pain which was mostly described as prickling in character was usually felt in the immersed hand as soon as the immersion started. The pain continued and increased in severity for about 3-4 minutes. During this period, most of the subjects suf- 
fered from tightness sensation in the chest and some experienced mild headache at the same time. Then, all the symptoms subsided gradually with the appearance of numbness sensation in the immersed hand. The pain disappeared in the last 3-4 minutes of the immersion, but it persisted in considerable severity for some subjects throughout the 10 minute immersion. After removal of the hand from the cold water, pain usually reappeared in the immersed hand especially around the border of the immersed and the non-immersed area for about 2-3 minutes, but much milder in severity. Then, an unpleasant warming sensation, usually throbbing in character, was felt and some of the subjects complained of itching sensation over the immersed hand in this stage. Generally, all the discomfort vanished in about 5 minutes after removal of the hand from the cold water. On the other hand, in the case of water at $10^{\circ} \mathrm{C}$, the pain usually came a little slower and milder. Accompanying symptoms were few and milder, if any. The pain also disappeared in the last 3-4 minutes of the immersion. However, some subjects reported that the pain seemed to persist about 2-3 minutes longer than in the case of water at $5^{\circ} \mathrm{C}$ in feeling, though the severity was a little milder in the case of water at $10^{\circ} \mathrm{C}$. After removal of the hand from the cold water, pain and itching sensation were seldom experienced. And the throbbing warming sensation was milder and disappeared a little sooner than in the case of water at $5^{\circ} \mathrm{C}$.

\section{Others}

There was no significant difference in rewarming response between the 13 patients with past history of Raynaud's phenomenon and the other patients, nor between the 16 patients of the stage II and the 13 of the stage III.

\section{DISCUSSION}

Cold water immersion test, though the procedure may differ among authors in some aspects, has been used to evaluate the peripheral vascular function or as a provocative test for Raynaud's phenomenon for many years. ${ }^{16-20)}$ However, it should be kept in mind that the skin temperature can be influenced by many factors including the external and the internal environmental conditions of the subject, e.g. ambient temperature, seasonal air temperature, humidity, wind velocity, functions of the cardiovascular system, temperature of the circulating blood, metabolic state of the surrounding tissues, mental status, functions of the central nervous system and the autonomic nervous system, etc. So, when the skin temperature is to be used as an index for evaluating the peripheral vascular function, no satisfactory result can be obtained unless the multiple influencing factors are well controlled and kept constant.

The pattern of temperature change in the immersed finger of the present study was similar to that presented by other authors. ${ }^{12}$, 15,17) Hunting reaction was observed in both cases of water at $5^{\circ} \mathrm{C}$ and $10^{\circ} \mathrm{C}$ in students and patients. The students showed more and stronger hunting reaction than the patients especially in the case of water at $5^{\circ} \mathrm{C}$. However, for most of the students and the patients, even in the case of water at $5^{\circ} \mathrm{C}$, the reaction was not so remarkable in frequency and intensity as that presented by Lewis ${ }^{15)}$ or Yoshimura and Iida. ${ }^{16)}$ The difference was thought to be due to the higher water temperature and shorter duration of immersion in the present study. So, if the hunting reaction is to be used as a primary diagnostic index, lower water temperature and longer duration of immersion had better be applied.

After removal of the hand from the cold water, the skin temperature of the immersed finger rose rapidly and almost linearly in the first 5-6 minutes in either case of water temperature for both the students and the patients. So, it is reasonable to evaluate the rewarming response in that period, especially in the first three minutes. Both the students and the patients showed the fact that the stronger the stimulus is, the greater is the response. The results shown in Table 1 suggest that water at $10^{\circ} \mathrm{C}$ can also be an effective stimulus, if the immediate rewarming response is used for evaluation. And among the three indices for 
the immediate rewarming response, recovery activity seems to be the best, because its $p$ value is the smallest. However, rewarming rate may also be used, because it can be calculated most easily.

As to the response in the non-immersed hand, most of the patients showed less remarkable response than the students. The response in the non-immersed hand is mainly evoked by the reflex related to the autonomic nervous system and the central nervous system. Disturbance in either of the two systems can affect the response in the non-immersed hand. And the individual difference in response to stress and adaptability to cold may also modify the response. Though less response in the non-immersed hand of the patients can not be immediately regarded as a pathological finding, it is an interesting and may be an important finding in diagnosing vibration disease. Abnormal electroencephalographical findings and disturbances in the autonomic nervous system have been observed in patients with Raynaud's phenomenon by de Takats and Fowler ${ }^{21)}$ and in patients with vibration disease by Futatsuka et al. ${ }^{22)}$ and Matoba et al. ${ }^{8)}$ So, it is reasonable to consider vibration disease as an entity of systemic disease.

It is not always true that patient with past history of Raynaud's phenomenon would show poor rewarming response to cold water immersion. Paradoxically, some patients without history of Raynaud's phenomenon showed very poor rewarming response in this study. Therefore, both the history and the result of the test should be taken into consideration in evaluating the peripheral vascular function of the patient with vibration disease.

Concerning the suffering during the test, the self-rating scores revealed the suffering was milder in the case of water at $10^{\circ} \mathrm{C}$ than at $5^{\circ} \mathrm{C}$. And the severe pain in the immersed hand seemed to be the most undesirable burden for both the students and the patients. As shown in Fig. 4, the pain was usually felt severest at the second minute of immersion. Generally speaking, the first 5 minutes was the hardest period for the subjects during the test. It might also be an important finding that the patients seemed to suffer more chest discomfort than the students in both cases: Because the suffering during the immersion test is so severe, attention should always be paid especially in the case of water at $5^{\circ} \mathrm{C}$ or lower temperature. To my experience from group examinations, most of the accidents occurred in the first 5 minutes of immersion (mostly in the case of water at $5^{\circ} \mathrm{C}$ ). Warning symptoms include distress in the chest, headache, nausea, gastralgia, intensive shivering, edema of the immersed hand, etc. Usually the symptoms were mild and would only last for a short time. However, some subjects had to quit the immersion test because of developing severe or long-lasting warning symptoms. For these subjects, a warm room or just a warm blanket can relieve them soon and effectively. Medication is seldom needed. Special caution should be used whenever immersion test is to be applied, especially to the high-risked subjects such as those with hypertension, cardiovascular disorders, hypersensitivity to cold or pain, and the aged. In principle, cold water immersion test should not be applied to them.

From the viewpoint of medical ethics, any kind of test should be safe and cause least suffering and be effective at the same time. The results of this study revealed that cold water immersion test is not a comfortable test even in the case of water at $10^{\circ} \mathrm{C}$. However, before more suitable and comfortable method can be applied, cold water immersion test may be used in group examination with caution.

\section{CONCLUSIONS}

The results of this study revealed that both the water at $5^{\circ} \mathrm{C}$ and $10^{\circ} \mathrm{C}$ can be used for immersion test. However, either case of water temperature has its merit and demerit.

Water at $5^{\circ} \mathrm{C}$ seems to be better than water at $10^{\circ} \mathrm{C}$ in view of the hunting reaction and the late rewarming response after removal of the hand from the water. However, water at $5^{\circ} \mathrm{C}$ usually causes severe suffering during the immersion and may induce undesirable symptoms. On the other hand, water at $10^{\circ}$ $C$ usually causes less suffering, And it can 
be and effective stimulus, if the immediate rewarming response is used for ievaluation. So, practically, water at $10^{\circ} \mathrm{C}$ seems to be more acceptable and safer than water at $5^{\circ} \mathrm{C}$.

Acknowledgements. I am much indebted to Prof. Makoto Takamatsu, Dr. Katsuyoshi Maeda and Dr. Tsunetaka Matoba for their valuable advice and fruitful discussions, and to the patients and the students for their willing cooperation. Thanks are also due to Dr. Hisao Kusumoto and Head Nurse Miss Sadako Nagao and the nurse staff of Yufuin Kosei Nenkin Hospital for their kind assistance.

\section{References}

1) Loriga, G.: [Cited by Taylor, W., in Taylor, W. (Ed.) The Vibration Syndrome, 3, Academic Press, London, 1974.]

2) Agate, J. N.: An outbreak of cases of Raynaud's phenomenon of occupational origin, $\mathrm{Br}$. J. Ind. Med., 6: 144-163, 1949.

3) Marshall, J., Poole, E. W. and Reynard, W. A.: Raynaud's phenomenon due to vibrating tools-neurological observations, Lancet, No. 6823: 1151-1156, 1954.

4) Miura, T., Kimura, K., Tominaga, Y. and Kimotsuki, K.: On the Raynaud's phenomenon of occupational origin due to vibrating tools, J.

- Sci. Labour, 42(11) : 725-747, 1966. (in Japanese)

5) Smith, A. R. B. and Allen, J. G.: Vibration disease, Med. J. Aust., 1: 901-905, 1969.

6) Watanabe, S. and Yamada, S.: The Prevention and Research of Vibration Disease in Soviet Forestry, 86-87, Sankosha, Tokyo, 1972. (in Japanese)

7) Takamatsu, M. and Futatsuka, M.: Hakurōbyō (white wax disease) as a systemic disease, Rōdōnokagaku, $24(8): 10-15,1969$. (in Japanese)

8) Matoba, T., Kusumoto, H., Kuwahara, H., Inanaga, K., Oshima, M., Takamatsu, M. and Esaki, K. : Pathophysiology of vibration disease, Jap. J. Ind. Health, $17(1): 11-18$, 1975. (in Japanese)

9) Yamada, S. : Hakurōbyō (white wax disease) due to the vibration of chain saw, Rōdōnokagaku, 20(12): 20-26, 1965. (in Japanese)

10) Yamada, S.: in Nisho, M. and Shoji, $H$ (Eds.) Human-made Disaster and Health, 161205, Koseikan, Tokyo, 1967.

11) Jepson, R. P.: Raynaud's phenomenon in workers with vibratory tools, $\mathrm{Br}$. J. Ind. Med., $11(3)$ : 180-185, 1954.
12) Iwata, H. : Finger temperature and Raynaud's phenomenon resulting from the use of the vibrating tools (2), Jap. J. Ind. Health, 10(3) : 119-123, 1968. (in Japanese)

13) Konishi, M., Yamaguchi, H., Koike, S. and Ishikawa, K.: The effect of smoking on the finger-tip plethysmogram, Jap. J. Hyg., 24 (2) : 318-327, 1969. (in Japanese)

14) Yamada, S. : Unpublished material.

15) Lewis, T.: Observations upon the reactions of the vessels of the human skin to cold, Heart, 15: 177-208, 1930.

16) Yoshimura, H. and Iida, T.: Studies on the reactivity of skin vessels to extreme cold, Jap. J. Physiol. 1: 147-159, 1950. (in Japanese)

17) Wolff, H. H. and Pochin, E. E.: Quantitative observations on vascular reactions in human digits in response to local cooling, Clin. Sci., 8: 145-154, 1949.

18) Hsieh, A. C. L., Nagasaka, T. and Carlson, L. D.: Effects of immersion of the hand in cold water on digital blood flow, J. Appl. Physiol., 20(1) : 61-64, 1965.

19) Okada, A., Yamashida, T. and Ueda, M. : Studies on the Raynaud's phenomenon of occupational origin, Jap. J. Ind. Health, $9(2): 3$ 11, 1967. (in Japanese)

20) Teisinger, J.: Vascular disease disorders resulting from vibrating tools, J. Occup. Med., $14(2)$ : 129-133, 1972.

21) de Takats, G. and Fowler, E. F.: Raynaud's phenomenon, J. Am. Med. Assoc. 179(1) : 99106, 1962.

22) Futatsuka, M., Teruya, H., Harada, M., Matsumura, K. and Goto, T. : Electroencephalographic studies on forestry workers using vibrating tools, Clin. Electroencephalogr., 16 (11) : 690-694, 1974. (in Japanese)

\section{和 文要 旨}

現在振動病診断に利用されている冷水浸漬試験は多く の場合 $5^{\circ} \mathrm{C}$ の冷水に片手を手関節まで 10 分間浸漬 し，手指の皮膚温反応をみるといら方法が採用されてい る. しかし, この方法では, 被検者に与える苦痛も大き く，時として，試験を中止せざるをえない場合も生ず る. そこで, 被検者の苦痛を軽減し，しかも検査精度を 大きく落すことのない方法として, $10^{\circ} \mathrm{C}$ 冷水 10 分間 浸漬法の有効性と苦痛の程度について検討を加えた。

学生 16 名および振動病患者 29 名について, 水温 $5^{\circ} \mathrm{C}$ と $10^{\circ} \mathrm{C}$ の二種の浸漬試験を行ない, 手指皮膚温 反応を検討するととるに試験中の苦痛について五段階自 己評価法によりその経過を調べた。 その結果次のことが 
明らかとなった。

1） $10^{\circ} \mathrm{C}$ 法に打ける浸漬中止後の皮膚温の回復傾向 は $5^{\circ} \mathrm{C}$ 法における回復傾向と有意の相関を示した.

2）検查精度からみれば，浸漬中止直後の 3 分間の回 復傾向で評価すれば, $10^{\circ} \mathrm{C}$ 法も有効である. とくに recovery activity (回復能) と rewarming rate（3 分 間皮濾温平均上昇率) とには，学生と患者との間に有意 差がみとめられて，指標として利用できる。
3）苦痛についての自己評価では, 学生も患者も $10^{\circ}$ $\mathrm{C}$ 法のほうが $5^{\circ} \mathrm{C}$ 法よりも苦痛が軽かった. 苦痛のう ち, 胸のしめつけ感は学生よりも患者のほうがより強く 訴えた.

以上の結果から, $10^{\circ} \mathrm{C}$ 法で recovery activity ない し rewarming rate を指標とするならば, 検査精度を 大きく落すことなく，被検者の苦痛は軽減できることが 明らかとなった。

Reprint requests to Department of Environmental Health, Kurume University School of Medicine, 67, Asahi-machi, Kurume, 830 Japan (C.P. Chang) 著者への通信先 : 張 正博, T 830 久留米市旭町 67 久留米大学医学部環境衛生学教室 